\title{
Effects of wood chip amendments on the revegetation performance of plant species on eroded marly terrains in a Mediterranean mountainous climate (Southern Alps, France)
}

\author{
Vincent Breton $^{1}$, Yves Crosaz ${ }^{2}$, and Freddy Rey $^{1}$ \\ ${ }^{1}$ Univ. Grenoble Alpes, Irstea, UR Ecosystèmes montagnards, BP 76, 38402 Saint-Martin-d'Hères, France \\ ${ }^{2}$ Géophyte, 64 rue des Ecrins, 38530 Pontcharra, France
}

Correspondence to: Vincent Breton (vincent.breton@irstea.fr)

Received: 18 January 2016 - Published in Solid Earth Discuss.: 21 January 2016

Revised: 25 March 2016 - Accepted: 29 March 2016 - Published: 15 April 2016

\begin{abstract}
The establishment of plant species can limit soil erosion dynamics in degraded lands. In marly areas in the Southern French Alps, both harsh water erosion and drought conditions in summer due to the Mediterranean mountainous climate prevent the natural implementation and regeneration of vegetation. Soil fertility improvement is sometimes necessary. With the purpose of revegetating such areas, we aimed to evaluate the effects of wood chip amendments on the revegetation performance of different native or subspontaneous plant species. We conducted two experiments on steep slopes over three growing seasons (2012-2014). The first consisted of planting seedlings (10 species), and the second consisted of seeding (nine species including six used in the first experiment). First we noted that wood chips were able to remain in place even in steep slope conditions. The planting of seedlings showed both an impact of wood chip amendment and differences between species. A positive effect of wood chips was shown with overall improvement of plant survival (increasing by $11 \%$ on average, by up to $50 \%$ for some species). In the seeding experiment, no plants survived after three growing seasons. However, intermediate results for the first and second years showed a positive effect of wood chips on seedling emergence: seeds of four species only sprouted on wood chips, and for the five other species the average emergence rate increased by $50 \%$.
\end{abstract}

\section{Introduction}

Soil erosion and flooding degrade terrestrial ecosystems and affect vegetation development (Garcia-Ruiz et al., 2015). Considerable research has been conducted on the functioning and protection of soils from degradation, bringing the issues of soil conservation and the importance of soil ecosystem services to the forefront (Keesstra et al., 2012; Brevik et al., 2015). The protective role of vegetation against erosion processes is well known, as stated by Stokes et al. (2014). Other studies also showed the effectiveness of mulch and litter in reducing soil erodibility in a context of agricultural production (Keesstra et al., 2016; Prosdocimi et al., 2016). Given that a plant's functional traits determine the suitability of species to limit soil erosion (Stokes et al., 2009; Burylo et al., 2014), the choice of plant species in bioengineering structures is essential. Numerous methods commonly used for revegetation of degraded lands use living materials, which are able to resist hydrological and erosive forces on a sloping site. Three sources of propagules can be highlighted: (i) seeds that are possibly present on topsoil (soil seed bank) or brought by different techniques (seeding, hydroseeding), (ii) plants and (iii) cuttings. However, eroded areas often do not offer satisfactory conditions to support natural colonization or artificial revegetation due to soil loss as well as low water and nutrient availability. Therefore, the success of bioengineering works and revegetation operations can depend on previous stages of soil fertility improvement (Donn et al., 2014; Young et al., 2015).

One way to improve soil conditions is to apply an organic amendment to the soil surface. Numerous studies have 
assessed the value of organic amendments on vegetation establishment and soil fertility, as for contaminated areas (Mahmoud and Abd El-Kader, 2015), post-mine soils (Eldridge et al., 2012; Benigno et al., 2013), semi-arid conditions (Hueso-González et al., 2014; Jiménez et al., 2013; Tejada and Benítez, 2014) and eroded soils (Ojeda et al., 2003; Cohen-Fernández and Naeth, 2013; Prats et al., 2013; Hosseini Bai et al., 2014; Donn et al., 2014; Hueso-González et al., 2015). Others have also shown the direct effect of organic mulch in reducing surface runoff (Moreno-Ramón et al., 2014; Cerda et al., 2015; Sadeghi et al., 2015). These organic amendments can have different forms: manure, green waste compost, straw, wood chips, etc. They can be incorporated into the soil or surface applied. The type of amendment and the application requirements depend on site conditions (access, topography, soil). The effects, in particular when surface applied (mulch), mainly concern the soil water availability (van Donk et al., 2012). This practice conserves soil water by rainfall interception and reduction of soil evaporation. It also reduces surface runoff and moderates soil temperature (Scopel et al., 2004).

Wood chips of small branches (Lemieux, 1988) are a form of organic amendment. Their use is developing, in particular on certain crops, even if validation provided by the scientific literature is incomplete (Barthès et al., 2010). Likewise, considering natural processes, the role played by woody litter on humus formation in forest ecosystems has not been sufficiently studied (Berg and McClaugherty, 2008). These latter authors admitted furthermore that white-rot fungi play an important role in woody material decomposition processes. The capacity of wood chips to improve the nutrient status of the soil depends on a quick and efficient stage of decomposition of organic matter and therefore on white-rot fungi presence and action. Therefore, Lemieux (1988) advised using low-diameter branches (less than $7 \mathrm{~cm}$ ), which have a low carbon-to-nitrogen ratio and limit nitrogen removal used for wood degradation. Moreover, considering lignin resistance to degradation, it is recommended to favor deciduous trees rather than coniferous trees (Stevanovic, 2007).

In marly catchments of the French Southern Alps, extensive areas are subjected to intense soil water erosion, resulting in climatic events such as torrential floods specific to this mountainous Mediterranean climate: wetting-drying cycles, frost in winter, high-intensity rainfalls in summer and consequently high sediment yields transported by floods at the exit of catchments (Yamakoshi et al., 2009). Experimental knowledge for ecological restoration of marly eroded lands is available through the voluminous research conducted in these areas (Rey, 2009; Erktan et al., 2016; Burylo et al., 2014). These studies have researched gully beds, where vegetation can counter erosive forces and trap sediment (Rey and Burylo, 2014; Rey and Labonne, 2015). Therefore it appeared that vegetation could also be profitable in gully slopes where soil fertility is very low (soil loss, low soil moisture and lack of an organic layer) and where natural vegetation is nearly nonexistent. The slopes are covered by a hard regolith layer, and vegetation cannot be established with the techniques currently used in gully beds, especially willow cuttings buried in soil. Planting and seedling methods for installing vegetation on slopes are therefore required. Such methods have already been tested on several other eroded lands (Reubens et al., 2009; Bochet et al., 2010; Fernández et al., 2012; Commander et al., 2013; Lee et al., 2013), but these studies did not apply to our climatic, topographic and pedological conditions, and the studied plant species are not appropriate or currently available. Therefore, the main issue for practitioners is to find the adequate solution to develop vegetation cover on gully slopes. The hydrological and erosive forces are generally less marked than on gully floors but occasionally they can be strong. As on slopes and floors, the vegetation must allow both withstanding hydrological forces and trapping sediment as quickly as possible. The low fertility of the soil, which is in the form of a regolith layer composed of coarse particles embedded in a matrix of finer material, is evident on gully slopes: export of nutrients, very low water and nutrient availability, with no accumulation or mineralization of organic matter. For this reason, soil fertility improvement appears necessary.

Here, we focused on crushed wood chips of small branches, considering that due to its size and form, this material may be better able to remain in place on slopes, compared to other forms of common amendment, finer and easily exported by runoff. This study aimed to test the effects of wood chip amendments on the revegetation performance of plant species on eroded marly terrains in a Mediterranean mountainous climate in the French Southern Alps. We hypothesized that in a context of water erosion and drought conditions of marly eroded land, the wood chip amendment, if able to remain in place, could facilitate plant establishment. The first point was subjected to empirical observation. The second point was based on precise measurements on plants (counting, height, etc.). This study was based on two experiments, representative of two methods for installing vegetation: planting of seedlings and seeding (cuttings were dismissed owing to compactness and scarcely penetrable soil). They were carried out over three growing seasons (20122014). Different plant species were tested: 13 species -6 were used in the two experiments - among those currently used and available in local tree nurseries, and a priori adapted to the type of environment under study.

\section{Methods}

\subsection{Site description}

The site is located in the French Southern Alps $\left(44^{\circ} 9^{\prime} \mathrm{N}\right.$, $6^{\circ} 21^{\prime}$ E) near Digne in Alpes-de-Haute-Provence (Fig. 1), in a badland area composed of gullies. The climate is mountainous and sub-Mediterranean, showing summer droughts with often intense rainstorms. Over the three growing seasons of 


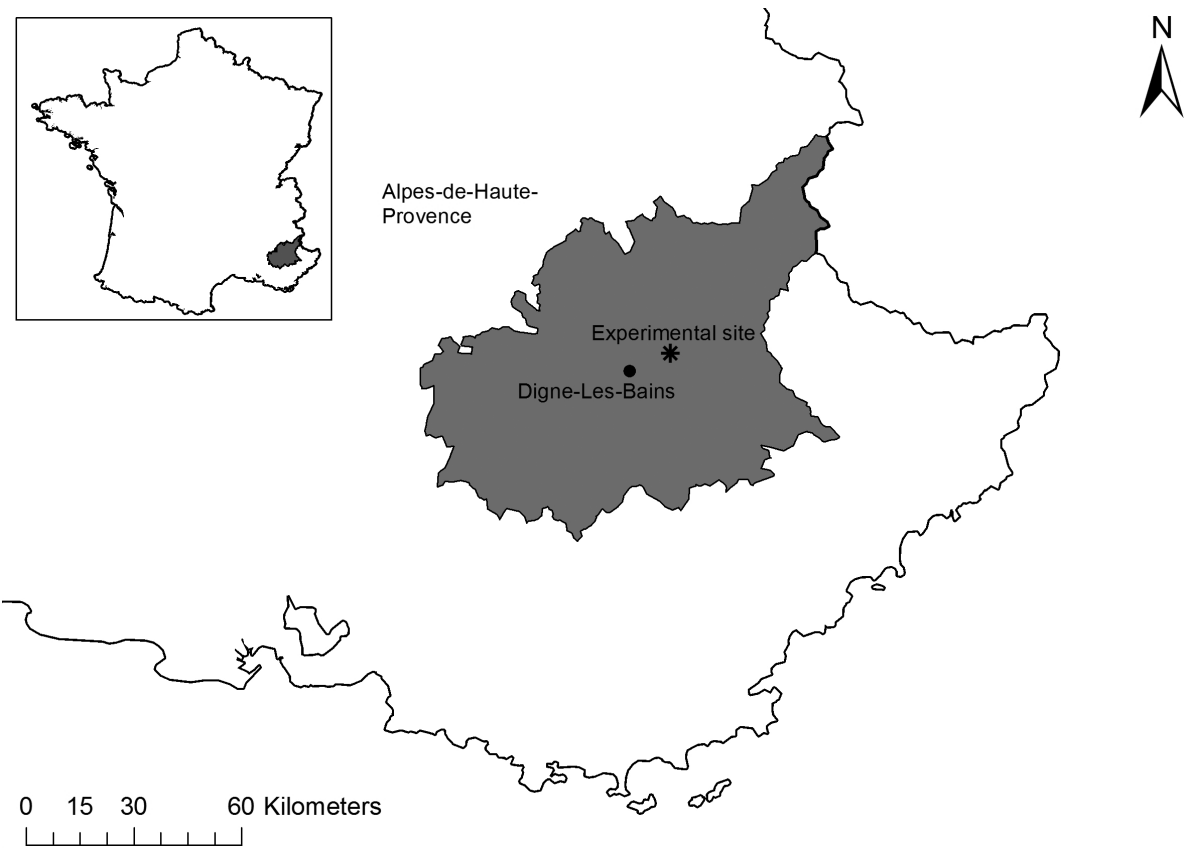

Figure 1. Location of the experimental site.

the experiments (2012-2014), the description of climatic parameters was based on data from the Sévigné meteorological station, $800-1000 \mathrm{~m}$ far from both experimental sites. During this period, the mean annual total rainfall was $920 \mathrm{~mm}$ and the average annual temperature was $10.2^{\circ} \mathrm{C}$. High climatic variations were observed both on the season scale $\left(20^{\circ} \mathrm{C}\right.$ differences in monthly temperatures between winter and summer) and on the year scale (long drought period in 2012). The 2012 summer drought was particularly severe: June and July showed a rainfall deficit of 67 and $83 \%$, respectively, compared to 30 -year averages. Even more fluctuating are the intense rainfall events: rainstorms generally occur randomly and can be very heavy, especially in summer. Some rainfall intensities can reach $70 \mathrm{~mm} \mathrm{~h}^{-1}$ lasting $1 \mathrm{~h}$ (Rey, 2009). Over the 3-year period, all the most intense events (more than $50 \mathrm{~mm} \mathrm{~h}^{-1}$ lasting at least $15 \mathrm{~min}$ ) occurred from the last 2 weeks of June to the end of August (once in 2012, three times in 2013, twice in 2014).

The soil composition depends on topographic conditions and alternates between a loose regolith layer made of disintegrated black marl fragment on the slopes and black marl sediment mainly on gully beds. The top layers are made of coarse marl fragments within a fine silty matrix and present low carbonate content, from 20 to $35 \%$, with $\mathrm{pH}$ varying from 7.8 to 8.1 (Wijdenes and Ergenzinger, 1998). The slope gradient is relatively steep, reaching $75 \%$ in most cases on the steepest parts of the gullies. Spontaneous vegetation is present in a dispersed manner, mainly on the lower and higher parts of gullies and rarely on the slopes. The dominant tree species is Pinus nigra, and the shrub layer is mainly composed of $J u$ - niperus communis, Hippophae rhamnö̈des and Buxus sempervirens. Even more dispersed are Ononis fruticosa, Lavandula officinalis and Robinia pseudo acacia.

\subsection{Plant and seed materials}

We conducted two experiments to study two modes of revegetation over three growing seasons: (1) planting seedlings of 10 plant species, hereafter designated as "plant experiment', and (2) seeding of nine plant species (Table 1), hereafter designated as "seed experiment". Six species were used in both experiments - Acer campestre L., Alnus cordata (Loisel.) Duby, Buxus sempervirens L., Hippophae rhamnoïdes L., Juniperus communis L. and Lavandula officinalis Chaix. Four species were tested only in the first experiment - Quercus pubescens Willd., Pinus nigra Arnold, Robinia pseudo acacia L. and Salix caprea L. - and three species only in the second experiment - Dorycnium pentaphyllum Scop., Anthyllis vulneraria L. and Ononis natrix L. This set consists of ligneous and semi-ligneous species, mainly shrubs that commonly grow in eroded marly lands around the two experimental sites (except Alnus cordata). The choice of the species and the method of vegetation installation (young plants or seeds) depended on the plant material availabilities in the local tree nurseries and accorded with results of previous local studies (mentioned above, especially Burylo et al., 2014).

Wood chips came from woody wastes of small branches after tree pruning in local public parks. It was mainly composed of poplars, lindens and plane trees. In the two cases, the wood chips were mixed and spread on the soil surface after seedling or planting operations, and formed a homoge- 
Table 1. List of species tested in the two experiments and seed density (for species tested in the seed experiment).

\begin{tabular}{|c|c|c|}
\hline \multicolumn{2}{|l|}{ Tested in one experiment } & \multirow[t]{2}{*}{$\begin{array}{l}\text { Seed density } \\
\text { (number } / \mathrm{m}^{2} \text { ) }\end{array}$} \\
\hline In the plant experiment & In the seed experiment & \\
\hline Quercus pubescens Willd. (Que) & Dorycnium pentaphyllum Scop. (Dor) & 4000 \\
\hline Pinus nigra Arnold (Pin) & Anthyllis vulneraria L. (Ant) & 8000 \\
\hline Robinia pseudo acacia L. (Rob) & Ononis natrix L. (Ono) & 4000 \\
\hline Salix caprea L. (Sal) & & \\
\hline \multicolumn{3}{|l|}{ Tested in both experiments } \\
\hline \multicolumn{2}{|c|}{ Acer campestre L. (Ace) } & 120 \\
\hline \multicolumn{2}{|c|}{ Alnus cordata (Loisel.) Duby (Aln) } & 580 \\
\hline \multicolumn{2}{|c|}{ Buxus sempervirens L. (Bux) } & 120 \\
\hline \multicolumn{2}{|c|}{ Hippophae rhamnoïdes L. (Hip) } & 190 \\
\hline \multicolumn{2}{|c|}{ Juniperus communis L. (Jun) } & 190 \\
\hline \multicolumn{2}{|c|}{ Lavandula officinalis Chaix (Lav) } & 1600 \\
\hline
\end{tabular}

In parentheses: species abbreviations.

neous $5 \mathrm{~cm}$ thick layer. The total volume of wood chips used to cover the different plots was $2 \mathrm{~m}^{3}$ (almost $1 \mathrm{~m}^{3}$ per experiment, corresponding to $500 \mathrm{~m}^{3} \mathrm{ha}^{-1}$ ). The seed densities depended on the species tested and were chosen according to the supplier's recommendations (Table 1). Because of the soil hardness, plant establishment required boring a $5 \mathrm{~cm}$ diameter and $17 \mathrm{~cm}$ deep hole with a drilling machine. This size corresponded to the size of the plant containers of all the species tested that were supplied by a local tree nursery.

\subsection{Experimental design}

For the two experiments, half of the surface area was covered with wood chips. The plant experiment consisted of five randomized completed blocks composed of two plots (wood chips and control). Each plot was composed of four replicates arranged in a row, and each row was composed of 10 single trees of each species tested (Figs. 2 and 3). Each plot covered $4 \mathrm{~m}^{2}$. The seed experiment consisted of three randomized blocks divided into nine plots corresponding to the plant species. Each plot was divided in two $1 \mathrm{~m}^{2}$ half-plots corresponding to the soil treatment (wood chips or control). Each half-plot was $1 \mathrm{~m} \times 1 \mathrm{~m}$ and divided into four $0.25 \mathrm{~m}^{2}$ sub-plots (Figs. 2 and 3). For the two experiments the blocks were generally placed in separate gullies. They were dispersed over an approximately 1 ha surface area, as far as possible on similar ecological conditions (slope, soil, water erosion).

\subsection{Observations and measurements}

The experiments were carried out over three growing seasons (2012-2014). Measurements and observations were conducted three times a year in order to divide the growing seasons: (i) at the end of May, (ii) at the end of July or the beginning of August and (iii) at the end of September or the beginning of October. This frequency allowed us to observe the rhythm of plant development during the growing seasons and to evaluate the effect of certain climatic parameters.

We quantified the seedling emergence of seeds by counting the number of seedlings of plant species sown on each sub-plot. The possibility of emergence of other plant species was also sought. For the plant experiment, seedlings were considered alive if living tissues in leaves, buds or stems were observed. We measured the plant height from the ground to the terminal bud of the tallest stem. The latter parameters were measured three times a year. The stem basal diameter was measured at the root-shoot junction only once a year at the end of the growing season. Compared to growth in height, we considered that growth in diameter was very low and did not need more than one measurement per year. For each measurement, an empirical observation of the state of the wood chip plots was made (export, covering, degradation).

\subsection{Statistical analysis}

Most of the data were non-normal, following different distributions and requiring nonparametric analysis. It was also necessary to involve random effects. We fitted generalized linear mixed models (GLMMs; Bolker et al., 2009) that can be performed on both normal and non-normal data and allowed us to analyze both fixed effects (soil treatment, species in the two experiments) and random effects (plot). Seedling emergence data were modeled using a GLMM with a Poisson distribution. Data on young plant mortality were analyzed with a binomial distribution. Young plant growth data (diameter, height) were analyzed using the linear mixed model with a normal distribution. These analyses allowed us to research the effect of soil treatment that is composed of only two modalities (wood chips or control) with likelihood ratio 


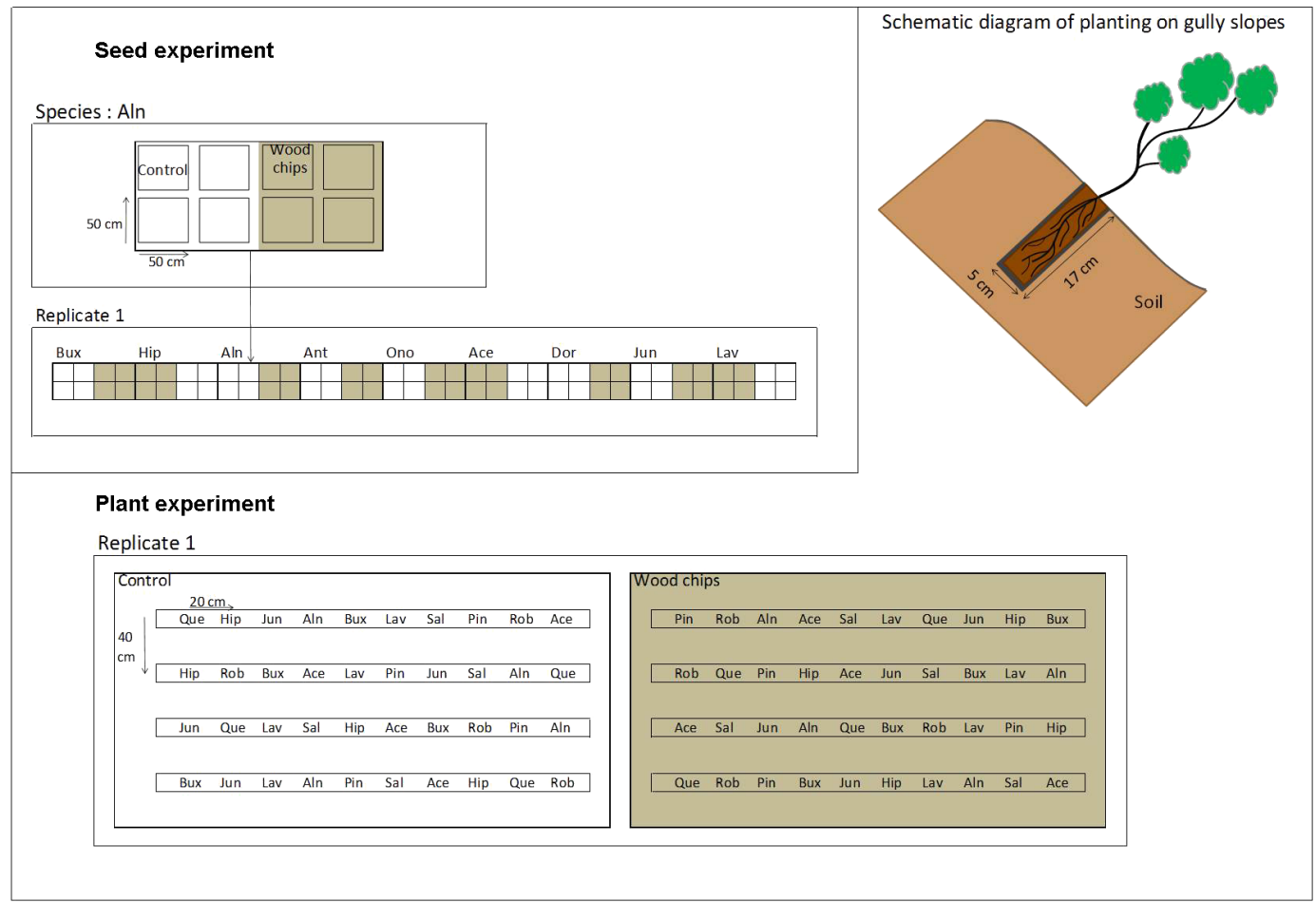

Figure 2. Experimental design of the two experiments (see species abbreviations in Table 1).
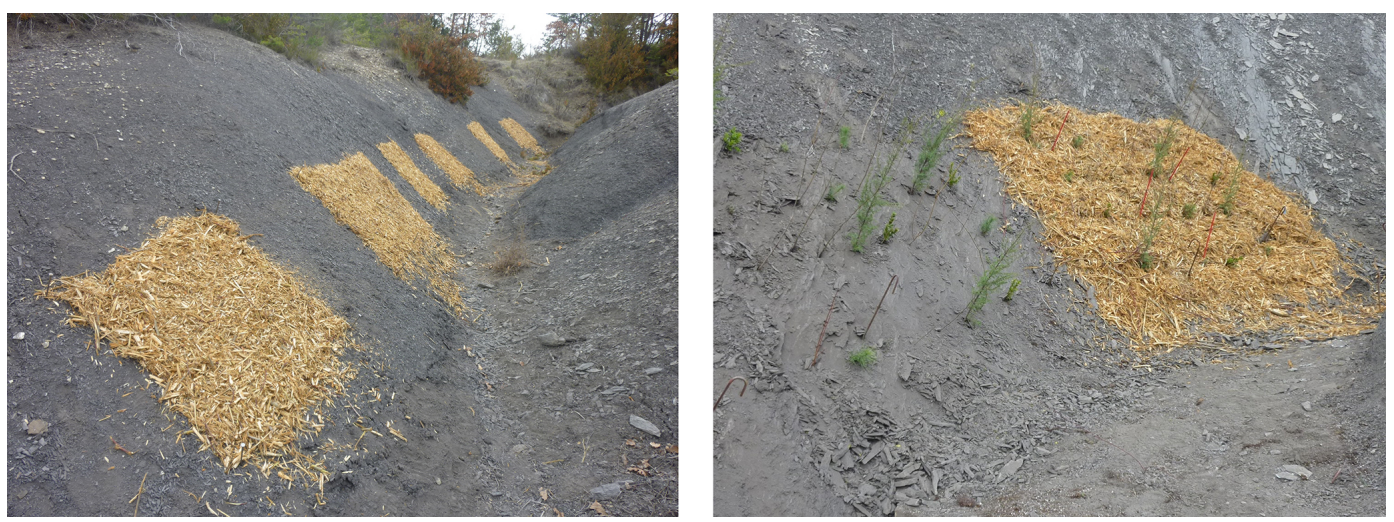

Figure 3. Pictures of the seed experiment setup (left) and the plant experiment setup (right).

tests. The species effect was also indicated but the differences between species cannot be known.

Seedling emergence data correspond to the maximum of seedlings out of the initial number of seeds in each plot, during the first year, the second year and all 3 years. Young plant survival data correspond to the number of living trees after the first, second and third growing seasons. The growth data were transformed to obtain relative data, with a difference between final measurement and initial measurement divided by initial measurement, in order to minimize the effect of initial plant size. All data were analyzed with the $R$ statistical packages lme4.

\section{Results}

\subsection{Wood chip observations}

Over the 3 years, we clearly noted that wood chips remained in place and were hardly ever carried away by surface runoff. During the first few months (first and second measurements), white-rot fungi presence was observed for all the plots and seemed to increase the cohesion of wood material. For the next 2 years, the white-rot fungi were not as visible. However, the material was partly covered by sediment. 


\subsection{Plant experiment}

Considering plant survival, the experiment showed a significant effect of both species $(p=0.003)$ and soil amendment $\left(p<10^{-3}\right.$, Table $\left.2 \mathrm{a}\right)$. The rate of survival quickly decreased with Alnus cordata, Lavandula officinalis and Salix caprea to almost $0 \%$ from the first growing season. They were removed for further analysis. The best survival rates were observed with Acer campestre, Quercus pubescens, Pinus nigra, Robinia pseudo acacia and Buxus sempervirens, which exceeded $50 \%$. The two other species, Hippophae rhamnoïdes and Juniperus communis, had intermediate results. A substantial positive effect of wood chip amendment on the survival rate was clearly observed with these two species: respectively, a 35 and $25 \%$ higher survival rate with wood chips. Most mortalities occurred during the summer period of the first year (Figs. 4 and 5), which corresponded to the most severe drought in comparison with the next 2 years.

Concerning the growth of young plants, significant effects were observed (i) for soil amendment with diameter and height measurements and (ii) for species with diameter only (Table 2a). There was a marked difference in the species ranking between diameter and height results (Fig. 6). For instance, Pinus nigra showed higher relative growth in height than in diameter. On the contrary, Quercus pubescens and Hippophae rhamnoïdes showed higher growth in diameter than in height. Differences in plant architectural forms were obvious, with a shrubby form that showed no apical dominance (especially Hippophae rhamnoides) and an arborescent form (especially Pinus nigra and Robinia pseudo acacia). Moreover, some species (Acer campestre, Quercus pubescens) showed some dried apical stems, leading to problems assessing the initial plant growth and the comparison between species. Nevertheless, the results were very good for Robinia pseudo acacia and Pinus nigra, which doubled in height (and doubled in diameter for Robinia pseudo acacia) before the end of the third year, and for Buxus sempervirens to a lesser extent, which reached a $50 \%$ relative growth increase at that date. Conversely, we noted very low growth of Quercus pubescens, Juniperus communis and Acer campestre, which did not show real growth after three growing seasons.

\subsection{Seed experiment}

In all sub-plots we did not identify other species than the species sown. Analyses revealed that the effect of species and soil amendment were significant in 2012 and 2013 (Table 2b). The date of emergence (Fig. 7) separates two groups of species: (i) Alnus cordata, Hippophae rhamnoïdes, Dorycnium pentaphyllum, Anthyllis vulneraria and Ononis natrix, which sprouted mainly in the first year, and (ii) Acer campestre, Buxus sempervirens, Juniperus communis, Lavandula officinalis, which sprouted mainly in the second year. In both cases, no plant survived longer than one
Table 2. (a) Plant experiment: likelihood ratio tests for fixed effects (soil treatment in species) based on (1) generalized mixedeffect models (GLMMs) for plant survival and (2) linear mixedeffect model (LMM) for relative growth during the first three growing seasons. (b) Seed experiment: likelihood ratio tests for fixed effects (soil treatment and species) based on GLMMs for maximum seedling emergence.

\begin{tabular}{|c|c|c|c|c|}
\hline \multirow[t]{10}{*}{ (a) } & Effect & Year & $\chi^{2}$ & $p$ value \\
\hline & Survival & & & \\
\hline & Soil amendment & & 8.60 & 0.003 \\
\hline & Species & & 150.7 & $<0.001$ \\
\hline & Relative growth in diameter & & & \\
\hline & Soil amendment & & 7.48 & 0.006 \\
\hline & Species & & 124.98 & $<0.001$ \\
\hline & Relative growth in height & & & \\
\hline & Soil amendment & & 44.31 & $<0.001$ \\
\hline & Species & & 0.09 & 0.764 \\
\hline \multicolumn{5}{|l|}{ (b) } \\
\hline & & 2012 & & \\
\hline & Soil amendment & & 22.72 & $<0.001$ \\
\hline & Species & & 427.25 & $<0.001$ \\
\hline & & 2013 & & \\
\hline & Soil amendment & & 309.14 & $<0.001$ \\
\hline & Species & & 379.73 & $<0.001$ \\
\hline & & overall & & \\
\hline & Soil amendment & & 183.77 & $<0.001$ \\
\hline & Species & & 164.59 & $<0.001$ \\
\hline
\end{tabular}

growing season. Three species sprouted new leaves for only one season (Hippophae rhamnoïdes, Alnus cordata and Lavandula officinalis). The others sprouted shoots over two seasons (Fig. 7). We observed an obvious positive effect of wood chip amendment for most species during the first two growing seasons. Some of them showed emergence capacity only with wood amendment: Alnus cordata, Lavandula officinalis, Buxus sempervirens, Acer campestre and Juniperus communis. The significance was clear even if it almost disappeared and no plants survived after the second growing season. Systematically the emergence rate decreased over the growing season. Whatever the year and the species, a higher rate always occurred in spring and it decreased during summer and autumn (Fig. 7).

\section{Discussion}

Although based on empirical observations, we noted that wood chips remained in place during the observation period. On the basis of the meta-analysis of García-Ruiz et al. (2015), who compared numerous studies on erosion rates around the world, we can reasonably consider our experi- 

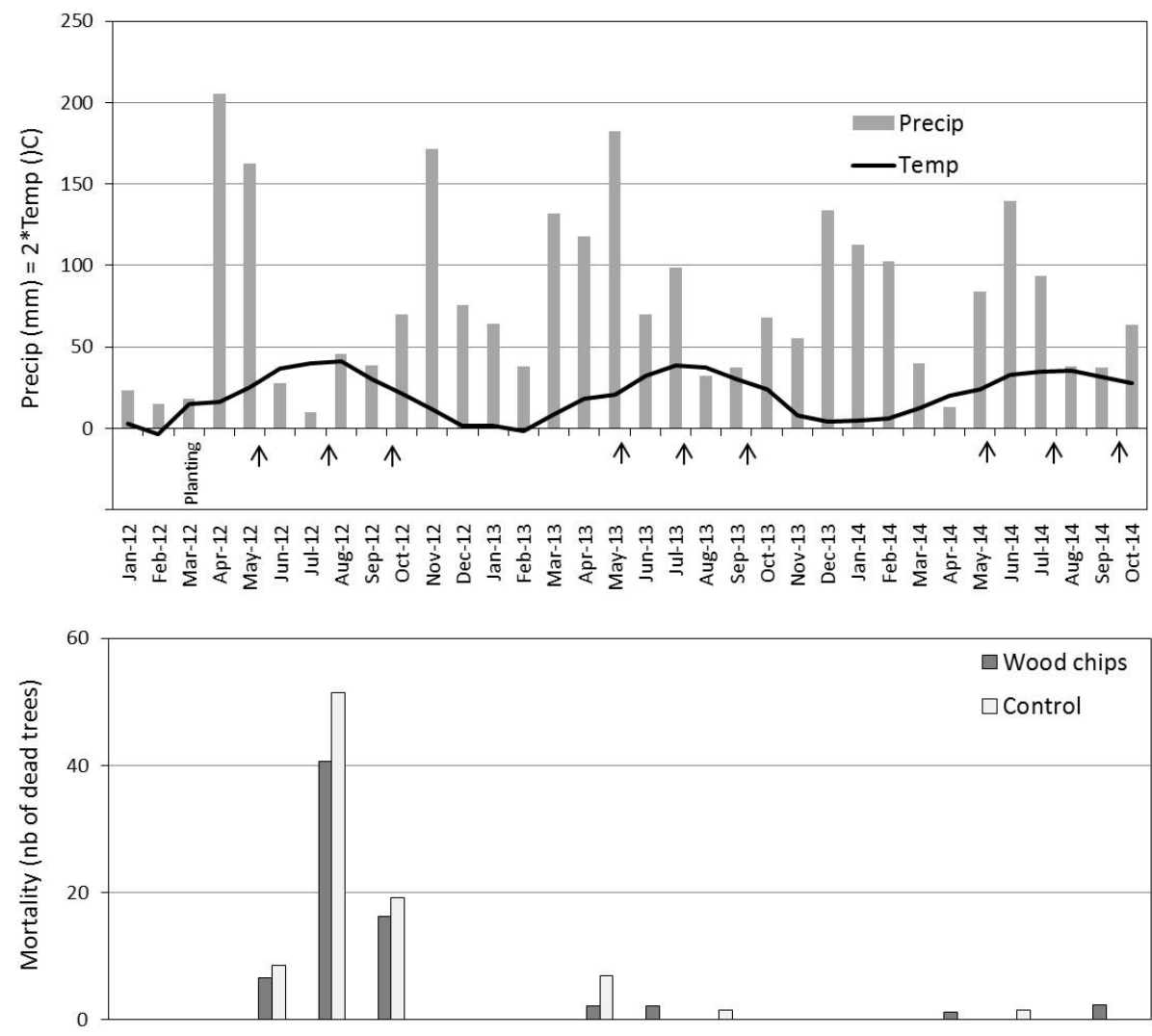

Figure 4. Mortality rate of seedlings (bottom: number of dead trees observed from the next assessment) and climatic parameters during the three growing seasons (ombrothermic diagram with monthly rainfall $(\mathrm{mm})=2 \times$ monthly temperature, ${ }^{\circ} \mathrm{C}$ ). Black arrows indicate the observation dates. Mortality rates were calculated from dead plants per stage referred to the live plants at the previous stage.

mental plots under very steep slope gradients and moderate mean annual precipitation. Moreover, local and particular events with very intense rainfall are possibly frequent in summer and were observed during the 3 years. So, according to the climatic and topographic factors observed during the study period, wood chips seem able to remain in place under severe erosive constraints.

Wood chips offered the best results with seeds as well as young plants. The benefit was (i) evident as regards seedling emergence and plant survival and (ii) less efficient as regards plant growth. For the first point, these findings are in agreement with the reported performance of various mulches preserving soil water and consequently promoting seedling establishment (Woods et al., 2012; Benigno et al., 2013; Hosseini Bai et al., 2014).

The positive effect on seedling emergence was obvious, although it did not last over 2 years. For four species, it only occurred with wood chip amendment: Buxus sempervirens, Acer campestre, Juniperus communis and Lavandula officinalis. For the five others, the positive effect of wood chips was often significant. We must also consider the possibility of the soil seed bank effect on seedling emergence. In each plot, we did not identify other species than the one sown. We cannot dismiss natural emergence from the soil seed bank (instead of sowing); considering the very low spontaneous emergence rate in the vicinity of sown plots, this possibility appeared unlikely. These results are consistent with previous research on seedling emergence (Eldridge et al., 2012; Benigno et al., 2013) where soil treatment and tested plant species were different. Cerdà and García-Fayos (2002) and Bochet (2015) noted the influence of the size and shape of seeds in their removal by water erosion. Our results are partly consistent, considering that the heaviest seeds (especially Acer campestre) were completely removed on untreated plots, but we did not have sufficient measurements on the seeds of the tested species to continue analysis of these criteria. The same holds true for the effect of runoff and sediment yield on seed removal studied by Han et al. (2011). It is obvious that wood chip amendment improved seed emergence capacity. As we cannot determine whether the decisive role is to avoid removal of seeds by water or to maintain soil moisture conditions, both cumulative effects must be considered. Other studies investigated the influence of organic amendment on the moisture of eroded soil (in particular Ojeda et al., 2003; Hueso-González et al., 2015), but the context of soils, types of amendment and slope gradi- 


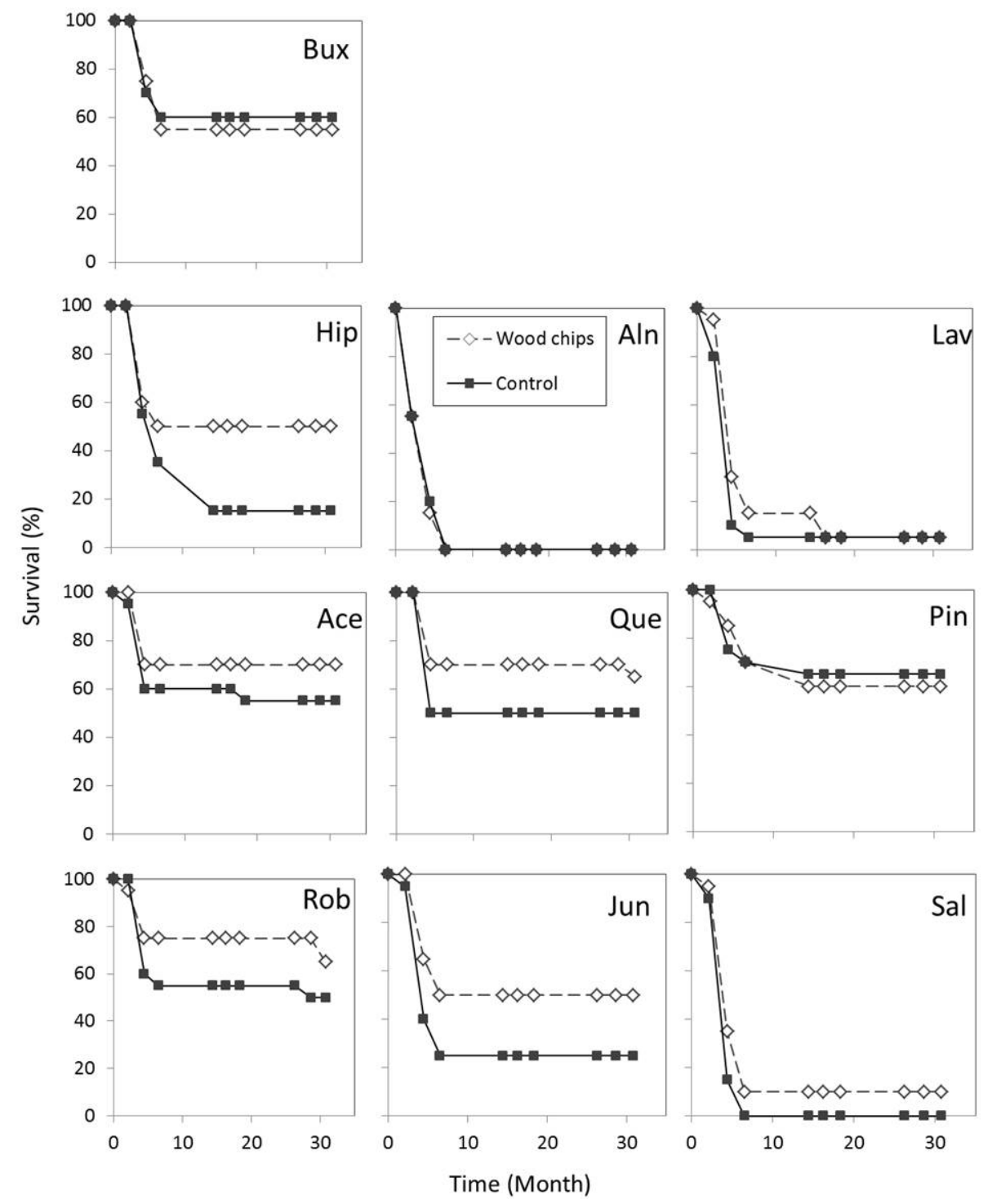

Figure 5. Plant experiment: comparison of survival rates between "wood chips" and "control" modalities, for three growing seasons after planting (see species abbreviations in Table 1).

ents were significantly different, and the comparison is not relevant. According to Bochet et al. (2007), soil water availability after rainfalls occurring during the germination period played a major role in seed germination. These authors and Crosaz (1995) also suggested that the species' ability to germinate under drought conditions could indicate a species' potential for success under semiarid conditions. In this way, considering the germinations during the strong drought period in 2012, we can assume some species' potentials, especially with Hippophae rhamnoïdes, Dorycnium pentaphyllum, Anthyllis vulneraria, Ononis natrix and finally Buxus sempervirens to a lesser extent, even if this ability did not last more than two seasons.

Regardless of soil treatment (wood chips or no wood chips), with an overall survival rate close to $50 \%$ (70\% for some species) after three growing seasons, the planting of seedlings appeared to be an efficient revegetation technique for gully slopes. In comparison, the advantage of seeding was not proved. Reserves in ligneous tissues seem to ensure the best chances against dry summer conditions during the critical establishment period. Most plant mortalities occurred during the first summer, which was the driest of the 3 years, and occurred very little during the following summer droughts. Another approach could be to associate seeding with drilling holes, as was experimented by Lee et al. (2013).

We also noted that differences in performance were generally greatest between species than between treatments (wood chips or control). The choice of species that were well adapted to drought conditions is essential and this study has provided additional data on that point. Several species 

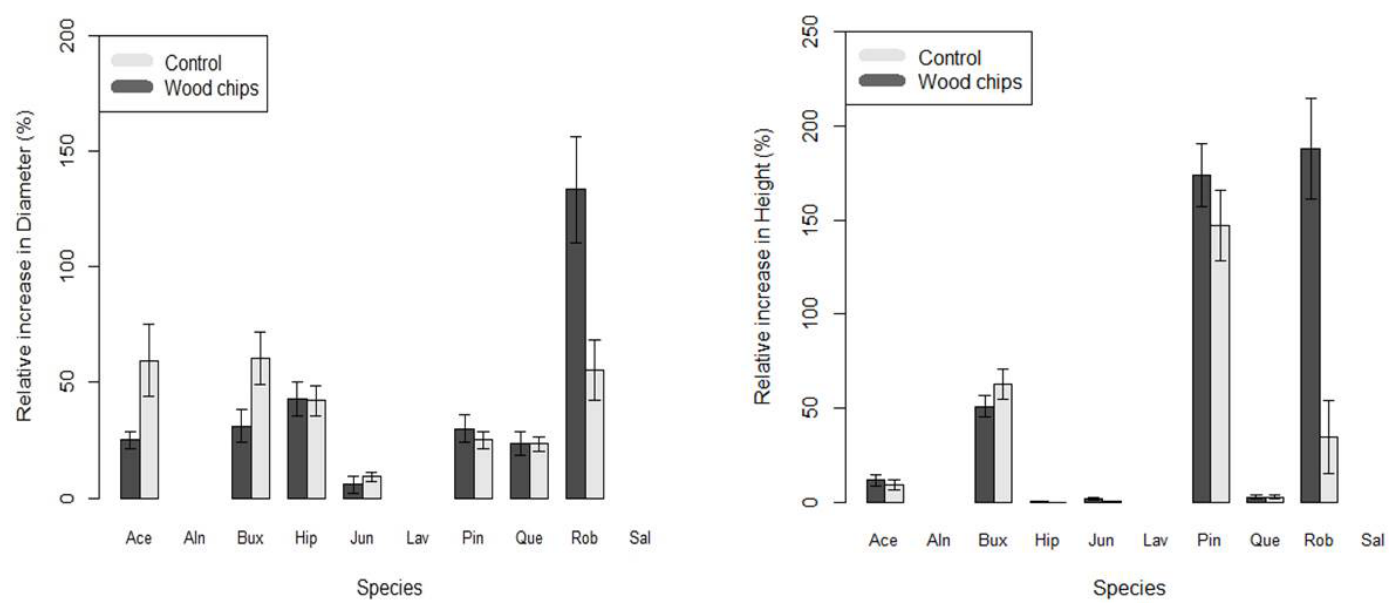

Figure 6. Relative increase in height (\%, left) and relative increase in diameter (\%, right) after three growing seasons. Bars indicate SE (see species abbreviations in Table 1).
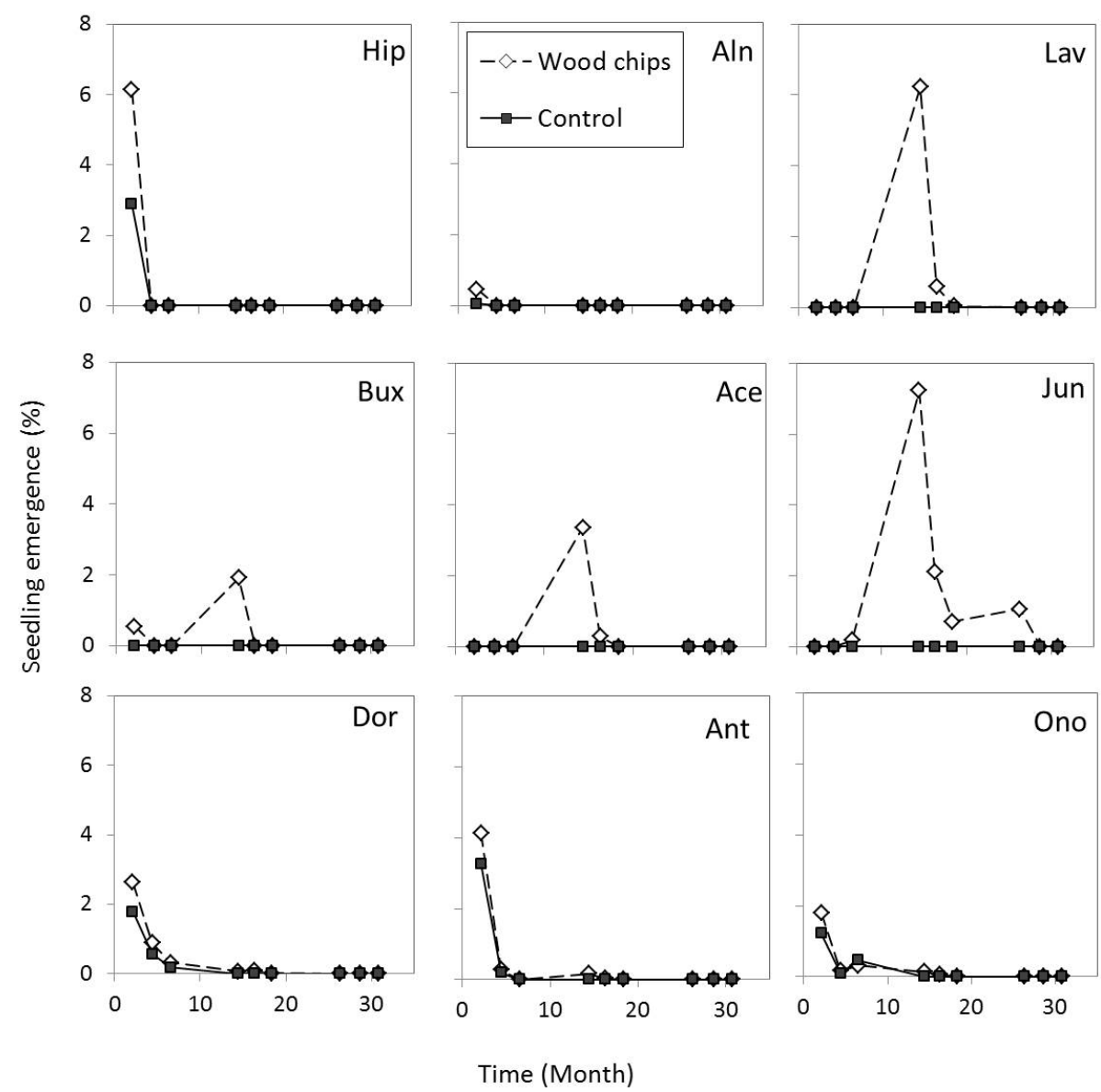

Figure 7. Effect of wood chips and comparison between species on seedling emergence for three growing seasons after seeding (see species abbreviations in Table 1).

showed the capacity to resist and remain in our experimental conditions (slopes, drought, flow erosion): Robinia pseudoacacia, Pinus nigra and Buxus sempervirens hold both sur- vival and growth capacities; Hippophae rhamnoïdes, Acer campestre and Quercus pubescens maintained a satisfactory survival rate. To meet the objective of revegetation, these 
species must also show performance for erosion control. Thanks to the synthesis work of Burylo et al. (2014), we have information on the response and effect traits of these species related to erosion dynamics in the same ecological conditions. The combined analysis of the two information sources allows us to improve the choice of appropriate plant species. Lastly, for the three species not tested in the young plant experiment (Dorycnium pentaphyllum, Anthyllis vulneraria, Ononis natrix), the field capacity on gully slopes was not known and will require additional experimentation.

Numerous studies have emphasized the value of organic amendment for revegetation and erosion control (see the introduction). The novelty value of our results concerns the positive effect of wood chips for revegetation in a steep slope context. Bochet and García-Fayos (2004) underscored "the difficulty of revegetating slopes with angles greater than $45^{\circ}$ $(100 \%)$, where the probability of seeds moving downhill is high." Other applications have to be examined in larger contexts of restoration and bioengineering works. The question of wood chip supply must be also considered. Considering the requirements for wood chips in revegetation works (deciduous trees, low-diameter branches), the supply of such material can be difficult. The commercial competition with other wood uses (the wood-energy industry in particular) and the low production margins that cannot support transport costs add further to these difficulties. As far as possible, solutions must be found in local production. This study has been carried out on small surface areas and with small quantities of mulch. Therefore it does not allow us to make a reliable analysis of the costs. In the experimental site, the supply of the wood chips cost between EUR 30 and $50 \mathrm{~m}^{-3}$ (between EUR 1.5 and $2.5 \mathrm{~m}^{-2}$ ). With large quantities, it is obvious that those prices must significantly decrease. Considering the total cost of the bioengineering project, the additional cost of wood chips (supply and application) represented a slight extent: $8-10 \%$ for the plant experiment. As the seeds were free of charge, this rate cannot be estimated for the seed experiment.

Finally, we must also investigate the contribution of these results for the bioengineering works in the context of eroded marly areas in the Southern French Alps. We already knew the possibilities and the limits of revegetation on gully beds (Rey and Burylo, 2014). The main objectives of our two experiments were to assess revegetation techniques on gully slopes. The outcomes allow us to establish the requirements in those conditions such as planting seedlings of certain plant species (especially Pinus nigra, Buxus sempervirens and Robinia pseudo-acacia) that can be improved by a wood chip layer, in addition to willow cuttings and wooden sills on gully beds. Such operations will require new experiments to test the two bioengineering techniques on slopes and beds at the same time. Revegetation by seeding cannot be recommended on the basis of our results, even though the failure can be explained by very dry climatic conditions during the first year. Further experiments should be considered, in par- ticular to determine whether seeding in autumn can limit the impact of a possible drought during the first growing season.

\section{Conclusions}

In the two experiments, the wood chip supply was distributed on steep slopes and in a context of water erosion. We showed that wood chips succeeded in remaining in place despite these erosive pressures and, at least during the first 2 years, have a positive effect on revegetation, mainly on plant survival and seed emergence capacities. This result is clearly confirmed in the seed experiment where, for several species, germination occurred only in the presence of wood chips during the second growing season, after intense rainfall events. The two experiments allowed us to test two methods of revegetation: planting of seedlings and seeding. We showed that revegetation on gully slopes is possible with the first method. The supply of wood chips can improve the establishment of young plants, limiting the mortality rate. The results with the seeding experiment were not as convincing. However, even if this study was limited in time, we noted seedling emergence capacity in association with wood chip amendment. All the possible applications of wood chips were not yet known, but we can consider that the gain in terms of plant survival and growth can be possibly decisive in revegetation work contexts, especially when extreme climatic events occur.

Author contributions. Vincent Breton, Freddy Rey and Yves Crosaz conceived the research and the experimental design (Yves Crosaz for the seeding experiment, Vincent Breton and Freddy Rey for the planting experiment). Vincent Breton (assisted by Yves Crosaz and Freddy Rey) took the measurements, made observations and analyzed the data. The manuscript was written and edited by Vincent Breton and Freddy Rey.

Acknowledgements. Funding was received from the IngecoTech CNRS-Irstea program and from Electricité de France (EDF), Agence de l'eau Rhône, Méditerranée et Corse, Région ProvenceAlpes-Côte-d'Azur and the European Union (FEDER Programme "L'Europe s'engage en PACA avec le Fonds Européen de Développement Régional"). We thank P. Bourduge (Zygène) and P. Boutteaud (Vilmorin) for the seed supply and their technical advice. We also thank E. Bayle (ONF), N. Daumergue and P. Tardif for advice and assistance in setting up the experiment. Irstea-Grenoble is part of Labex OSUG@2020 (ANR10 LABX56).

Edited by: A. Cerdà 


\section{References}

Barthès, B.-G., Manlay, R.-J., and Porte, O.: Effets de l'apport de bois raméal sur la plante et le sol : une revue des résultats expérimentaux, Cah. Agric., 19, 280-287, 2010.

Benigno, S. M., Dixon, K. W., and Stevens, J. C.: Increasing Soil Water Retention with Native-Sourced Mulch Improves Seedling Establishment in Postmine Mediterranean Sandy Soils, Restor. Ecol., 21, 617-626, 2013.

Berg, B. and McClaugherty, C.: Plant Litter. Decomposition, Humus Formation, Carbon Sequestration, Second edn., edited by: Springer, Berlin Heidelberg, Germany, 338 pp., 2008.

Bochet, E.: The fate of seeds in the soil: a review of the influence of overland flow on seed removal and its consequences for the vegetation of arid and semiarid patchy ecosystems, SOIL, 1, 131-146, doi:10.5194/soil-1-131-2015, 2015.

Bochet, E. and García-Fayos, P.: Factors Controlling Vegetation Establishment and Water Erosion on Motorway Slopes in Valencia, Spain, Restor. Ecol., 12, 166-174, 2004.

Bochet, E., García-Fayos, P., Alborch, B., and Tormo, J.: Soil water availability effects on seed germination account for species segregation in semiarid roadslopes, Plant Soil, 295, 179-191, 2007.

Bochet, E., García-Fayos, P., and Tormo, J.: How can we control erosion of roadslopes in semiarid mediterranean areas? Soil improvement and native plant establishment, Land Degrad. Dev., 21, 110-121, 2010.

Bolker, B. M., Brooks, M. E., Clark, C. J., Geange, S. W., Poulsen, J. R., Stevens, M. H. H., and White, J.-S. S.: Generalized linear mixed models: a practical guide for ecology and evolution, Trends Ecol. Evol., 24, 127-135, 2009.

Brevik, E. C., Cerdà, A., Mataix-Solera, J., Pereg, L., Quinton, J. N., Six, J., and Van Oost, K.: The interdisciplinary nature of SOIL, SOIL, 1, 117-129, doi:10.5194/soil-1-117-2015, 2015.

Burylo, M., Dutoit, T., and Rey, F.: Species Traits as Practical Tools for Ecological Restoration of Marly Eroded Lands, Restor. Ecol., 22, 633-640, 2014.

Cerdà, A. and García-Fayos, P.: The influence of seed size and shape on their removal by water erosion, Catena, 48, 293-301, 2002.

Cerda, A., González-Pelayo, O., Jordan, A., Pereira, P., Novara, A., Brevik, E. C., Prosdocimi, M., Mahmoodabadi, M., Keesstra, S., and Orenes, F. G.: The use of barley straw residues to avoid high erosion and runoff rates on persimmon plantations in Eastern Spain under low frequency â high magnitude simulated rainfall events, Soil Research, 54, 54-165, doi:10.1071/SR15092, 2015.

Cohen-Fernández, A. C. and Naeth, M. A.: Erosion control blankets, organic amendments and site variability influenced the initial plant community at a limestone quarry in the Canadian Rocky Mountains, Biogeosciences, 10, 5243-5253, doi:10.5194/bg-10-5243-2013, 2013.

Commander, L. E., Rokich, D. P., Renton, M., Dixon, K. W., and Merritt, D. J.: Optimising seed broadcasting and greenstock planting for restoration in the Australian arid zone, J. Arid Environ., 88, 226-235, 2013.

Crosaz, Y.: Lutte contre l'érosion des terres noires en montagne méditéranéenne. Connaissance du matériel végétal harbacé et quantification de son impact sur l'érosion, Université de droit, d'économie et des sciences-Aix-Marseille III, 1995.

Donn, S., Wheatley, R. E., McKenzie, B. M., Loades, K. W., and Hallett, P. D.: Improved soil fertility from compost amendment increases root growth and reinforcement of surface soil on slopes, Ecol. Eng., 71, 458-465, 2014.

Eldridge, J. D., Redente, E. F., and Paschke, M.: The Use of Seedbed Modifications and Wood Chips to Accelerate Restoration of Well Pad Sites in Western Colorado, USA, Restor. Ecol., 20, 524-531, 2012.

Erktan A., Cécillon L., Graf F., Roumet C., Legout C., and Rey F.: Increase in soil aggregate stability along a Mediterranean successional gradient in severely eroded gully bed ecosystems: combined effects of soil, root traits and plant community characteristics. Plant Soil, 398, 121-137, 2016.

Fernández, C., Vega, J. A., Jiménez, E., Vieira, D. C. S., Merino, A., Ferreiro, A., and Fonturbel, T.: Seeding and mulching + seeding effects on post-fire runoff, soil erosion and species diversity in Galicia (NW Spain), Land Degrad. Dev., 23, 150-156, 2012.

García-Ruiz, J. M., Beguería, S., Nadal-Romero, E., GonzálezHidalgo, J. C., Lana-Renault, N., and Sanjuán, Y.: A metaanalysis of soil erosion rates across the world, Geomorphology, 239, 160-173, 2015.

Han, L., Jiao, J., Jia, Y., Wang, N., Lei, D., and Li, L.: Seed removal on loess slopes in relation to runoff and sediment yield, Catena, 85, 12-21, 2011.

Hosseini Bai, S., Blumfield, T. J., and Reverchon, F.: The impact of mulch type on soil organic carbon and nitrogen pools in a sloping site, Biol. Fert. Soils, 50, 37-44, 2014.

Hueso-González, P., Martínez-Murillo, J. F., and Ruiz-Sinoga, J. D.: The impact of organic amendments on forest soil properties under Mediterranean climatic conditions. Land Degrad. Dev., 25, 604-612, doi:10.1002/ldr.2150, 2014.

Hueso-González, P., Ruiz-Sinoga, J. D., Martínez-Murillo, J. F., and Lavee, H.: Overland flow generation mechanisms affected by topsoil treatment: Application to soil conservation, Geomorphology, 228, 796-804, 2015.

Jiménez, M. N., Fernández-Ondoño, E., Ripoll, M. Á., CastroRodríguez, J., Huntsinger, L., and Navarro, F. B.: Stones and organic mulches improve the Quercus ilex L. afforestation success under Mediterranean climatic conditions, Land Degrad. Dev., 27, 357-365, doi:10.1002/ldr.2250, 2013.

Keesstra, S., Geissen, V., Mosse, K., Piiranen, S., Scudiero, E., Leistra, M., and van Schaik, L.: Soil as a filter for groundwater quality, Current Opinion in Environmental Sustainability, 4, 507-516, 2012.

Keesstra, S., Pereira, P., Novara, A., Brevik, E.C., AzorinMolina, C., Parras-Alcántara, L., Jordán, A., and Cerdà, A.: Effects of soil management techniques on soil water erosion in apricot orchards, Sci. Total Environ., 551-552, 357-366, doi:1016/j.scitotenv.2016.01.182, 2016.

Lee, J. W., Park, C. M., and Rhee, H.: Revegetation of decomposed granite roadcuts in Korea: developing digger, evaluating cost effectiveness, and determining dimensions of drilling holes, revegetation species, and mulching treatment, Land Degrad. Dev., 24, 591-604, doi:10.1002/ldr.2248, 2013.

Lemieux, G.: L'importance du bois raméal dans la "synthèse de l'humus", Université Laval, Québec, Canada, 29 pp., 1988.

Mahmoud, E. and Abd El-Kader, N.: Heavy Metal Immobilization in Contaminated Soils using Phosphogypsum and Rice Straw Compost, Land Degrad. Dev., 26, 819-824, doi:10.1002/ldr.2288, 2015. 
Moreno-Ramón, H., Quizembe, S. J., and Ibáñez-Asensio, S.: Coffee husk mulch on soil erosion and runoff: experiences under rainfall simulation experiment, Solid Earth, 5, 851-862, doi:10.5194/se-5-851-2014, 2014.

Ojeda, G., Alcañiz, J. M., and Ortiz, O.: Runoff and losses by erosion in soils amended with sewage sludge, Land Degrad. Dev., 14, 563-573, 2003.

Prats, S. A., Malvar, M. C., Vieira, D. C. S., MacDonald, L., and Keizer, J. J.: Effectiveness of hydromulching to reduce runoff and erosion in a recently burnt pine plantation in central Portugal, Land Degrad. Dev., doi:10.1002/ldr.2236, 2013.

Prosdocimi, M., Jordán, A., Tarolli, P., Keesstra, S., Novara, A., and Cerdà, A.: The immediate effectiveness of barley straw mulch in reducing soil erodibility and surface runoff generation in Mediterranean vineyards. Sci. Total Environ., 547, 323-330. doi:10.1016/j.scitotenv.2015.12.076, 2016.

Reubens, B., Poesen, J., Nyssen, J., Leduc, Y., Abraha, A. Z., Tewoldeberhan, S., Bauer, H., Gebrehiwot, K., Deckers, J., and Muys, B.: Establishment and management of woody seedlings in gullies in a semi-arid environment (Tigray, Ethiopia), Plant Soil, 324, 131-156, 2009.

Rey, F.: A strategy for fine sediment retention with bioengineering works in eroded marly catchments in a mountainous mediterranean climate (Southern Alps, France), Land Degrad. Dev., 20, 210-216, 2009.

Rey, F. and Burylo, M.: Can bioengineering structures made of willow cuttings trap sediment in eroded marly gullies in a Mediterranean mountainous climate?, Geomorphology, 204, 564-572, 2014.

Rey, F. and Labonne, S.: Resprout and survival of willow (Salix) cuttings in marly gullies in a mountainous Mediterranean climate: a real size experiment in the Francon catchment (Southern Alps, France), Environ. Manage., 56, 971-983, 2015.

Sadeghi, S. H. R., Gholami, L., Sharifi, E., Khaledi Darvishan, A., and Homaee, M.: Scale effect on runoff and soil loss control using rice straw mulch under laboratory conditions, Solid Earth, 6, 1-8, doi:10.5194/se-6-1-2015, 2015.

Scopel, E., Silva, F. A. M. D., Corbeels, M., Affholder, F., and Maraux, F.: Modelling crop residue mulching effects on water use and production of maize under semi-arid and humid tropical conditions, Agronomie, 24, 383-395, 2004.
Stevanovic, T.: Constituants chimiques du bois et utilisa agroécologique des bois raméaux fragmentés, in: Les rémanents en foresterie et agriculture. Les branches : matériaux d'avenir, edited by: TEC\&TOC, Lavoisier, Paris, France, 57-65, 2007.

Stokes, A., Atger, C., Bengough, A. G., Fourcaud, T., and Sidle, R. C.: Desirable Plant root traits for protecting natural and engineered slopes against landslides, Plant Soil, 324, 1-30, 2009.

Stokes, A., Douglas, G. B., Fourcaud, T., Giadrossich, F., Gillies, C., Hubble, T., Kim, J. H., Loades, K. W., Mao, Z., McIvor, I. R., Mickovski, S. B., Mitchell, S., Osman, N., Phillips, C., Poesen, J., Polster, D., Preti, F., Raymond, P., Rey, F., Schwarz, M., and Walker, L. R.: Ecological mitigation of hillslope instability: Ten key issues facing researchers and practitioners, Plant Soil, 377, 1-23, 2014.

Tejada, M. and Benítez, C.: Effects of crushed maize straw residues on soil biological properties and soil restoration, Land Degrad. Dev., 25, 501-509, doi:10.1002/ldr.2316, 2014.

van Donk, S. J., Lindgren, D. T., Schaaf, D. M., Petersen, J. L., and Tarkalson, D. D.: Wood chip mulch thickness effects on soil water, soil temperature, weed growth and landscape plant growth, Journal of Applied Horticulture, 13, 91-95, 2012.

Wijdenes, D. O. and Ergenzinger, P.: Erosion and sediment transport on steep marly hillslopes, Draix, Haute-Provence, France: an experimental field study, Catena, 33, 179-200, 1998.

Woods, S. R., Fehmi, J. S., and Backer, D. M.: An assessment of revegetation treatments following removal of invasive Pennisetum ciliare (buffelgrass), J. Arid Environ., 87, 168-175, 2012.

Yamakoshi, T., Mathys, N., and Klotz, S.: Time-lapse video observation of erosion processes on the Black Marls badlands in the Southern Alps, France, Earth Surf. Proc. Land., 34, 314-318, 2009.

Young, I., Renault, S., and Markham, J.: Low levels organic amendments improve fertility and plant cover on non-acid generating gold mine tailings, Ecol. Eng., 74, 250-257, 2015. 